\title{
The Effect of Self-Efficacy, Management Capability, and Internal Communication Onteachers' Organizational Commitment
}

\author{
Osberth Sinaga ${ }^{1}$, Munajat ${ }^{2}$, M. Joharis Lubis ${ }^{2}$ \\ ${ }^{1}$ Postgraduate Student at State University of Medan, Indonesia \\ ${ }^{2}$ Postgraduate Lecturer at State University of Medan, Indonesia \\ hoockland@yahoo.com
}

\section{Abstract}

This study aims to investigate the effect of Self-Efficacy, Management Ability, and Internal Communication on Teachers' Organizational Commitment at Dwi Warna Senior High School Medan. The amount of population is 52 people and the sample is 30 people. The distribution data shows that $62.30 \%$ is included in the Fair category and 37.70 in the less category. The data distribution of Self-efficacy categorizes that $65.90 \%$ is included in the fair category and $34.10 \%$ in the less category. The distribution of Management Capability data shows that $64.40 \%$ is included in the high category and $35.60 \%$ in the fair category. The distribution of Internal Communication data shows that $68.20 \%$ is included in the high category and $31.80 \%$ in the fair category. The results obtained from the calculation are 50.394. The $F$ table is calculated with the provisions of the significance level of $95 \%$ and alpha 5\% and degrees of freedom with provisions $n-1=29$. With these provisions obtained lift $F_{\text {table }}=$ 2,85 Thus the value of $F_{\text {count }}=50.394$, and $F_{\text {table }}=2.85$. Because $F_{\text {count }}>F_{\text {table }}$ which means that $H_{o}$ is rejected and $H_{a}$ is accepted, so it can be concluded that there is a significant simultaneous influence between self-efficacy, Management Capability, Internal Communication on Organizational Commitment.
Keywords

Self-Efficacy,

Management Ability, Internal

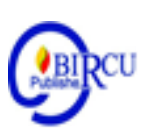

\section{Introduction}

Human resources are the most important assets in an organization because they are sources that control, maintain and develop the organization in dealing with the various demands of the times. Therefore, human resources must be considered, maintained, and developed. Likewise, educational institutions must pay attention to maintain and develop the human resources. They need to be developed continuously in order to obtain quality human resources so that the work carried out will produce the desired results.

Various efforts have been carried out by the government, in this case, the Ministry of Education and Culture does not have significant improvement in improving the quality of education. In line with Law Number 322004 concerning regional government autonomy, it has an impact on the implementation of education management that gives space, wider movement to the management of education. Moreover, it also finds competitive strategies in this era to achieve quality education, where teachers have the most leading role for the achievement of these objectives.

Organizational commitment is one important point for each individual to form an association. Organizational commitment is one of interesting topic to be observed at school 
because the committed teacher will produce better performance than the less committed. It can be seen from the characteristics of individual teachers or workers in improving the quality of teaching.

Teachers who show high commitment have a desire to provide more energy and responsibility in supporting the welfare and success of the organization where they work. They have high commitments who always try to improve the quality of the place where he works. By having commitment, teachers are expected to be loyal, to stay permanently at the school where they work.

Organizational commitment at Dwi Warna Senior High School plays an important role in achieving organizational goals, so the intensity of teachers with commitment from one another is very different regarding the assessment of the organization. Every profession has been set with a code of ethics that has been set and norms or rules, so it must be obeyed as well as possible

One of the problems at Dwi Warna Medan High School is teachers who have a low intensity of commitment to the organization or school. Teachers who do not teach at other school have a stronger commitment than teachers who teach at some schools. Qualified teachers have a high commitment to the school so that schools can develop more steadily and sustainably.

Research on organizational commitment needs to be conducted on teachers because teacher commitment at school can influence teacher behavior in teaching-learning process, in interacting with students, coworkers and faculty or school leaders. It also affects the productivity of teachers in conducting research, writing scientific articles, and providing services to the community. According to Setiadi (2002), the nature of organizational commitment is how the attitude and behavior of an employee towards the tasks assigned by the institution in which he works.

Based on preliminary studies, there are several factors that cause the absence of teachers in teaching and learning activities. The contributing factor to the low quality of education especially in Dwi Warna Senior High School is the problem of having a sense of moral responsibility. In general, teachers do not have a sense of moral responsibility at Dwi Warna Senior High School. Hence, the holders of the school have not been able to explore all the potential that exists in order to cooperate in supporting the optimal learning process.

The ineffectiveness of teacher commitments at Dwi Warna Senior High School, such as the expected target is not achieved, work that places too much emphasis on the final results so that group dynamics through communication and coordination occur so little that causes the low of interpersonal relationships. Moreover, physical loyalty reflected by how long a person is in the organization less visible among teachers. The conflict among teachers in the organization is due to lacks a sense of obligation so that it causes less effective resources. Other words, teachers have a high normative commitment because they feel that they are not obliged to survive in the organization and less have a sense of moral responsibility.

Responding to the above problems, the organizational commitment of teachers at Dwi Warna Senior High School in their performance and attitudes must be improved more effectively. Especially for teachers, most research highlights normative commitment. In implementing programs that are designed, the results of research show that there are many influential variables in realizing the programs that have been designed, one of which is having a strong commitment and determination to succeed. This shows that education managers do not have a normative commitment in solving problems of education quality. In 
order to run well, the teacher must have Organizational Commitment, love and cooperate with fellow teachers and their superiors.

Based on the results of research conducted by Colquitt, Lepine, and Wesson (2009: 8) it is found that empirically there are several variables that affect organizational commitment. This shows that various variables found in influencing organizational commitment. They are organizational culture, organizational structure, leadership style and behavior, power and influence of leadership, team, characteristics, cultural values and personality, and ability. It is in line with Gibson et al (2009: 169), communication influences commitment. This means that the better communication built by the leader with the teacher, the higher commitment they have. In other words, the communication and coordination between teacher and the leader influences the organizational commitment.

Organizational commitment is influenced by some factors, such as good communication, negotiation skills, internal and external support, clear advice, relevant skills, and mutual trust. They affect the effective team. Thus, good and strong communication will increase one's commitment, if a person has good communication in his work it will be able to increase commitment too.

Sopiah (2008: 155) explains that organizational commitment is an important behavioral dimension that can be used to assess the tendency of employees to stay as members of the organization. Organizational commitment illustrates the attitude of individual loyalty to the organization. It is also a process of expressing attention and participation to the organization.

Based on the description above, this study is conducted to investigate the effect of self-efficacy, management ability, and internal communication on organizational commitment of teachers at Dwi Warna High School Medan.

\section{Review of Literature}

\subsection{Organizational Commitment}

Commitment is the ability and willingness to align personal behavior with the needs, priorities and goals of the organization. This includes ways to develop goals or meet organizational needs that essentially prioritize the organization's mission rather than personal interests. Other words, it is individual's strong acceptance of goals and organizational values, and individuals to have a strong desire to keep the organization. Commitment plays an important role in the success of the work of an employee in an organization.

Employee commitment to the organization as a relative strength of the individual in identifying and engaging with the organization, which is characterized by acceptance of the values and goals of the organization, readiness and willingness to work hard and survive in the organization. It is clearly shows that employee commitment to the organization means more than passive loyalty, but involves active relationships and the desire of employees to make a meaningful contribution to their organization (Chairy, 2002).

In line with the above explanation, Miller (2003) defines employee commitment to the organization as a condition where the employee identifies himself with the organization and its objectives, and desires to maintain its membership in the organization. Therefore, employee commitment to the organization is the level where an employee is willing to maintain their membership because of their interest and relationship to the goals and values of the organization. Meanwhile, employee commitment as a behavior is based on the extent to which the individual determines the decision to be bound to the organization. 
According to Robbins (2008), employee commitment to the organization is to what extent an employee supports the organization and its objectives, and intends to maintain membership in that organization. Committed employees are employees who show high involvement in an organization. Darmawan (2013) states commitment is a tendency to be bound in a consistent line of activities because it considers the costs of implementing other activities.

Gibson (2009) states Commitment to an organization involves three attitudes: (1) a sense of identification with the organization's goals, (2) a feeling of involvement in organizational duties, and (3) a feeling of loyalty to the organization. Organizational commitment includes three attitudes, namely feelings of attachment to organizational goals, feelings of being involved in organizational activities and feelings of obedience to the organization.

Based on the description above, it is concluded that organizational commitment is a psychological condition that reflects the beliefs and acceptance of employees towards the goals and values of the organization, the desire to maintain membership in the organization and the willingness to try hard and work hard for the achievement of organizational goals. Teachers who have organizational commitment will do the best for the benefit of the organization, assuming that what is important must be achieved is the achievement of tasks in the organization and the desire to maintain membership in the organization. Operatively the commitment of the teacher organization is a quality relationship between school members that determines the steps to build trust in the relationship. The indicators are: strong desire to remain as a member of the organization, willing to sacrifice goals or personal interests to achieve organizational goals, desire to work hard and enthusiasm in work.

\subsection{Internal Communication}

Organizational communication is an interdependent system includes internal and external communication. Internal communication is communication within the organization itself such as communication from subordinates to superiors, communication from superiors to subordinates, communication between fellow employees of the same level.

According to Effendy (2009: 122) internal communication is the exchange of ideas between administrators and employees in an organization or agency that results in the realization of the organization complete with distinctive structures and the exchange of ideas horizontally and vertically in an organization that causes work to take place. Mangkunegara (2008: 145) defines that communication is the process of transferring information and understanding

Good communication is meant interwoven understanding between one party to another, so that what is communicated can be understood, thought and implemented. Without having good communication, the work becomes confusing and chaotic so that the organization's goals will most likely not be achieved. By having communication, someone will receive news and information in accordance with what is in their thoughts or feelings so that other people can understand.

Based on the above theory, it is concluded that internal communication is the exchange of ideas between teachers and superiors in an organization horizontally and vertically. Indicators of internal communication in this study are: 1). Positive attitude, positive feeling for the communication situation is very important for effective interaction, 2) equality, 3) respecting themselves and others by maintaining the feelings of others, so that satisfying 
interaction is reached, 4) openness, it contents honesty and has an open view in all situations and conditions.

\subsection{Management Capability}

In common sense, management is defined as cultivation, which is the process of organizing or managing an organization in achieving desired goals. Makmur (2009: 6) explains that management is the science and art of managing the process of utilizing human resources and other resources efficiently and effectively to achieve certain goals. Educational management implies as a systematic and comprehensive collaborative process in order to realize the goals of national education. Educational management can also be interpreted as anything related to the management of the education process to achieve the goals set as well as short, medium and long-term goals.

According to Rohman (2012: 29) Educational management is the process of developing a group of people working together to achieve the stated educational goals. The process of controlling these activities includes planning, organizing, mobilization and supervision, as a process to turn vision into action. Educational management is as the art and science of managing educational resources to create an atmosphere of learning process so that students actively develop their potential to have spiritual strength, self-control, personality, intelligence, noble character, and the skills needed by themselves and society.

Based on the theory above, it can be synthesized conceptually that the ability of management is the ability in the process of implementing management functions to achieve goals effectively and efficiently. Operationally, management ability is the cognitive ability of leaders in the process of implementing management functions to achieve goals effectively and efficiently, with indicators of planning, organizing, directing, and controlling educational resources.

\subsection{Self-Efficacy}

Self-efficacy is one of the most influential aspects of knowledge in daily human life. This is due to the self-efficacy affects the individual in determining the actions to achieve a goal, including the estimation of various events that will be faced. It is the belief that someone can master the situation and get positive results.

According to Ormrod (2008: 20) self-efficacy is a person's assessment of his own ability to carry out certain behaviors or achieve certain goals. Self-efficacy is one's belief that he is able to do certain tasks well. It has effectiveness, namely the individual is able to judge himself has the power to produce something desired. The high perceived self-efficacy will motivate the individual cognitively to act appropriately and directly. The individual's mind on self-efficacy determines how much effort is expended and how long the individual will persist in the face of obstacles or unpleasant experiences.

Alwisol (2009: 287) states that self-efficacy is as self-perception towards the goodness in certain situations. It is associated with the belief that someone has the ability to do the expected action. In line with the above opinion, Jess Gregory (2010) defines self-efficacy is as self-confidence to know their abilities so that they can exercise some form of control over the benefits of the person itself and events in the surrounding environment.

Based on the explanation stated above, operationally self-efficacy is the belief owned by the teacher about his ability to act in order to achieve the demands of school organizations, with indicators: confidence in involvement in the task, confidence in his ability to withstand challenges, and have an optimistic attitude. 


\section{Research Methodology}

This research is conducted at Dwi Warna Senior High School Medan. The population in this study is teachers at Dwi Warna Senior High School which consisted of 52 teachers, while the sample is 30 respondents.

Analysis of the data used in this study is descriptive analysis, test requirements analysis, and hypothesis testing. In accordance with the research hypothesis and research objectives, hypothesis testing is performed using regression analysis.

\subsection{Research Result}

\section{Discussion}

The description of the data presented in this section includes the data variable Selfefficacy (X1), Management Capability (X2), Internal Communication (X3), and Organizational Commitment (Y). The data are the result of the quantification of respondents' answers to the questionnaire distributed to teachers at Dwi Warna senior High School. Simultaneous hypothesis testing is needed to find out whether the regression model is correct or not. Hypothesis testing using the following F Test Result:

Table 1. Descriptive Research Data F-Test Results

\begin{tabular}{|c|c|c|c|c|c|}
\hline \multicolumn{6}{|l|}{ ANOVA } \\
\hline Model & $\begin{array}{l}\text { Sum } \\
\text { Squares }\end{array}$ & $\mathrm{f}$ & Mean Square & $\mathrm{F}$ & ig. \\
\hline $\begin{array}{l}\text { Regr } \\
\text { ession }\end{array}$ & 6404,110 & & 2134,703 & $0,394^{5}$ & 000 \\
\hline $\begin{array}{ll} & \text { Resid } \\
\text { ual } & \end{array}$ & 1101,357 & 6 & 42,360 & & \\
\hline Total & 7505,467 & 9 & & & \\
\hline \multicolumn{6}{|c|}{ a. Dependent Variable: Y } \\
\hline b. Predict & rs: (Constant), X3, X & 2,1 & & & \\
\hline
\end{tabular}

Hypothesis testing is perforemd by comparing the magnitude of the $\mathrm{F}$ number of research with $\mathrm{F}$ table, with the following criteria:

If $\mathrm{F}$ arithmetic $>\mathrm{F}$ table, then $\mathrm{Ho}$ is rejected and $\mathrm{Ha}$ is accepted

If $\mathrm{F}$ arithmetic $<\mathrm{F}$ table, then $\mathrm{Ho}$ is accepted and $\mathrm{Ha}$ is rejected

Based on table 1, the F number of the study obtained from the calculation is 50.394 . While the $\mathrm{F}$ number of the table is calculated with the provisions of significance level of $95 \%$ and alpha of $5 \%$ and degrees of freedom with the provisions of $n-1=29$. Under these conditions, the $\mathrm{F}$ table $=2.85$. Thus the value of Fcount $=50.394$, and Ftable $=2.85$. Because Fcount> Ftable which means that Ho is rejected and $\mathrm{Ha}$ is accepted, so it can be concluded that there is a significant simultaneous influence between self-efficacy (X1), Management Capability (X2), Internal Communication (X3) on Organizational Commitment (Y). 


\subsection{Discussion}

Self-efficacy provides perspective as self-confidence to know the abilities so self control can be carried. Individual thoughts on self-efficacy determine how much effort is expended and how long the individual will remain in the face of obstacles or experience discomfort. Expected self-efficacy among fellow teachers ultimately increases the organizational commitment of the teacher. It illustrates the beliefs and acceptance of the teacher towards the goals and values of the organization, the desire to maintain membership in the organization and the willingness to work hard for achievement of organizational goals. Based on the results of research, it can be concluded that self-efficacy has a positive and significant effect on normative commitment.

The ability of teachers in management is still low. This shows that teachers at Dwi Warna Senior High School do not have sufficient cognitive abilities to integrate educational resources so that they are centralized in the effort to achieve predetermined educational goals, where education management is a process for coordinating various educational resources such as teachers, educational facilities and infrastructure (libraries, laboratories, and so on) to achieve the goals and objectives of education well (Pidarta, 2004: 4). Management capabilities provide perspectives to enlighten the ideas. The aesthetic component of the leader triggers the possibilities and new perspectives. The application generates new ideas and different ways of approaching challenges and problems. Management capability is expected to have honesty in carrying out its leadership functions. Leaders have a desire to build mutual trust by setting an example and showing high consistency between words and actions. Leaders must be role models so that they will be able to increase the organizational commitment of the teacher.

By having communication, humans can interact each other. Communication in organization is a process of conveying information, ideas, between members of the organization in a reciprocal way in order to achieve the goals. Other words, among members of the organization, there is interaction with one another and receiving information, ideas and so on. It obtains an understanding or similarity in perception to achieve a common goal. Those who get organizational commitment, teachers usually have a record of attendance, active in union activities, and better performance

The results of this study are in line with research conducted by Triana (2013), in increasing the commitment of teacher organizations which illustrates the beliefs and acceptance of employees towards the goals and values of the organization, the desire to maintain membership in the organization and the willingness to work hard for the achievement of organizational goals. Organizational commitment defines as feelings of trust in organizational values, willingness to do the best for the interests of the organization and the desire to remain a member of the organization expressed by a teacher to the organization. Organizational Commitment of teachers at Dwi Warna Senior High School can be improved when satisfying interactions are achieved and have an open view in all situations and conditions.

\section{Conclusions}

Based on the data analysis and discussion of the result, the organizational commitment of teachers can be implemented for teachers at Dwi Warna Senior High School based on variables Self-efficacy, Management Capability and Internal Communication, with organizational commitment variables. The Organizational Commitment Model in this study 
shows that the increase in teacher organizational commitment can be done through strengthening self-efficacy, management ability. Self-efficacy directly leads to have better organizational commitment. In connection with the factors that influence Organizational Commitment, it is necessary to pay attention to the strengths and weaknesses of self-efficacy, management capability, internal communication in order to improve those factors which are perceived to increase Organizational Commitment cognitively, especially if the goal to be achieved is a clear.

\section{References}

Alwisol. 2009. Personality Psychology: Revised Edition. Malang: UMM Press.

Colcuit, Jason A., Jeffery A., LePine., And Michael J. Wesson. 2009. Organizational Behavior: improving performance and commitment in the workplace. New York: McGraw-Hill.

Chairy, Liche Seniati. 2002. Regarding Organizational Commitment. Depok: University of Indonesia.

Darmawan, D. 2003. Management Information Systems. Bandung: Rosda.

Effendy, Onong Uchjana. 2009. Communication Theory and Practice. Bandung: PT Remaja Rosdakarya.

Gregory Feist, Jess. 2010. Theoris of Personality. Jakarta: Salemba Humanika.

Gibson, J.L; Ivancevich, J.M; Donnelly, Jr. J.H; and Konopaske, R. 2009, Organizations: Behavior, structure, processes, 13th ed. Irwin, New York: McGraw-Hill.

Mangkunegara. A. P. 2008, Human Resource Management. Bandung: Remaja Rosdakarya.

Prosperous. 2009. Strategic Management Theory in Government and Development. Bandung: Refika Aditama.

Miller A. L. \& MacKay D. 2003. Nutritional Support for Wound Healing, Alternative Medicine Review, 8.

Ormrod, Jeanne. Ellis 2008. Educational Psychology Developing Learners Sixth Edition (Educational Psychology Volume 2, 6th Edition). Subtitles: Amitya Kumara. Jakarta: Erlangga.

Pidarta.Made. 2004. Management of Indonesian Education. Jakarta: Rineka Cipta.

Robbins SP, and Judge. 2008. Organizational Behavior 2. Jakarta: Salemba Empat.

Rohman Muhammad 2012. Educational Management. Jakarta: Prestrasi Pustakarya.

Setiadi J Nugroho. 2002. Consumer Behavior: Concepts and Implications for Business Marketing Strategy and Research. Prenada Media, Jakarta.

Sopiah 2008. Organizational Behavior. Yogyakarta: Andi.

Triana Kartika Sari and Andre D Witjaksono. 2013. The Effect of Organizational Culture On Organizational Commitment Through Employee Job Satisfaction. Journal of Managemen 